typical for students with lack or low manifestation of volitional self-regulation and ability to work in the field of "person - person"; fragmentary mastery of educational material; fragmentary knowledge about the subject area and the specifics of professional activity, organization of service and production process, etc.

Key words: future specialists, hotel and restaurant industry, preparedness, criterias, levels.

Дата надходження статmі: 12.05.2021 p.

Рецензент: доктор педагогічних наук, доцент Бордюг Н. С.

\author{
УДК 378.147 \\ DOI https://doi.org/10.37915/pa.vi49.266
}

Гуменюк I. М., orcid.org/0000-0002-0790-6732

\title{
ДІНГВІСТИЧНИЙ І ЕКСТРАЯІНГВІСТИЧНИЙ ПІДХОДИ В МЕТОДИЦІ НАВЧАННЯ УКРАЇНСЬКОЇ МОВИ ЗА ПРОФЕСІЙНИМ СПРЯМУВАННЯМ
}

Стаття присвячена вивченню потенціалу лінгвістичного та екстрахінгвістичного підходів до навчання дисцииліни «Українська мова за професійним спрямуванням» у педагогічних закладах вищої освіти. Завданням дослідження є висвітлення основних иляхів усунення орфоепічних, акцентуаційних, лексичних, синтаксичних і пунктуаційних недоліків професійного мовлення майбутніх учителів початкових класів у межах навчального курсу. Наоснові аналізу інформаційного простору проблеми встановлено, що перспективи застосування хінгвістичного підходу в контексті украйнської мови за професійним спрямуванням представлені незначною кількістю публікацій. Аексичний аспект професійного мовлення спрямований на формування термінологічної компетентності студентів і частково - на розкриття методики лексичної сполучуваності у фаховій мові та усунення лексичних помилок. Наголошено на актуальності проблем надмірного вживання пасивних дієслівних форм і неправильної побудови прийменникових конструкцій у писемному діловому мовленні, а також можливостях їх вирішення у межах курсу. Окреслено основні аспекти вдосконалення синтаксичного й пунктуаційного оформлення професійного мовлення студентів та невирішені питання у цъвому контексті.

Аінгвістичний підхід до навчання української мови за професійним спрямуванням охоплюе реалізаціюо прагмалінгвістичних категорій у професійній комунікацій, зокрема мікропрагматичних одиниць (рівень мовияя), макропрагматичних (рівень рецииієнта), мегапрагматичних (соизіальний рівень). Акцентовано на відсутності досліджень методики навчання особливостям застосування екстралінгвістичних засобів у професійному спілкуванні. Підтверджено необхідність інтегрованого застосування лінгвістичного підходу до навчання української мови за професійним спрямуванням поряд з іншими концеептуальними підходами до мовної освіти.

Ключові слова: професійне мовлення, лінгвістичний підхід, екстралінгвістичний підхід, лексична норма, синтаксична норма, прагмахінгвістичні категорії, комунікація, лінгвістична компетентність.

Постановка проблеми. Професійне мовлення знаходить своє вираження в усній та писемній формах української літературної мови. Дотримання орфоепічних, акцентуаційних, лексичних, фразеологічних та інших норм в усній професійній комунікації є показником інтелектуального та культурного рівня мовця, як і дотримання орфографічних, пунктуаційних, стилістичних норм у писемній формі. Тому лінгвістичний підхід до навчання української мови за професійним спрямуванням

*C) Гуменюк I. М.

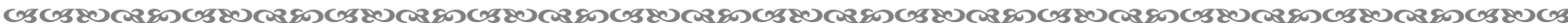
130 
інтегровано використовується разом з іншими концептуадьними підходами до мовної освіти. Більше того, на тих педагогічних спеціальностях, у навчальних планах яких відсутній курс «Сучасна українська мова 3 практикумом», українська мова за професійним спрямуванням залишається єдиною мовною дисципліною, чітко орієнтованою на формування дінгвістичної компетентності студентів.

Аналіз досліджень. 3 огляду на загальноприйняте професійно-комунікативне спрямування аналізованої дисципліни, дослідження перспектив застосування лінгвістичного підходу в іï контексті представдені недостатньо. Вивчення наукового інформаційного простору зазначеного питання показало, що найчисельнішу групу публікацій становлять праці, присвячені лексичному аспекту професійного мовлення, а саме - термінологічному. Серед 24-х проаналізованих (наявних у вільному доступі) досліджень тільки 2 спрямовані на розкриття методики лексичної сполучуваності у фаховій мові та усунення лексичних помилок. У змісті інших розкриваються особливості формування термінологічної компетентності студентів. Так, Т. Дещенко слушно наголошує, що саме через похибки в лексичній сполучуваності фахових слів виникають труднощі перекладу з близькоспоріднених мов, а також калькування і неправомірне використання таких запозичень, наприклад: брати участь (а не приймати участь на зразок рос. принимать участие), вжити заходів (а не прийняти міри на зразок рос. принимать меры), завдати шкоди (а не принести шкоду (рос. принести вред) та ін. [5]. На нашу думку, така порівняльно-мовознавча діяльність на заняттях з української мови за професійним спрямуванням сприятиме усвідомденому слововживанню, розумінню причин помилкового поєднання слів.

Необхідність роботи 3 усунення лексичних помилок у процесі навчання досліджуваного курсу обгрунтовує О. Пасічна. Авторська система вправ орієнтована на роботу з синонімічними рядами, розрізненні паронімів, узгодженні прикметниківпаронімів з іменниками, омонімії термінів і загальновживаних слів, а також міжмовної інтерференції [8]. У науковому полі зроблено також поодинокі спроби розкрити аспекти роботи з фразеологізмами в контексті української мови за професійним спрямуванням [2;6], однак вони не охоплюють специфіки використання усталених словесних формул у конкретному професійному середовищі.

Мета статті - визначення стану і шляхів реалізації лінгвістичного та екстралінгвістичного підходів у методиці навчання курсу «Українська мова за професійним спрямуванням».

Виклад основного матеріалу. Актуальною проблемою сучасного наукового й офіційно-ділового мовлення залишається надмірне вживання пасивних дієслівних конструкцій. Таке явище зумовлене переносом логічного наголосу із суб'єкта-діяча на об'єкт дії, так званим «знеособленням», властивим офіційному спілкуванню. Однак у багатьох випадках згадані конструкції втрачають логіко-граматичний зміст, на чому наголошуе в науковій розвідці 3. Куньч [4]. Серед неправильних конструкцій дослідниця виділяе випадки вживання назви особи у формі орудного відмінка (Педагогічними працівниками повинна здійснюватися навчально-виховна робота), використання пасивних дієприкметників замість безособових форм на -но, -то (На рисунку показана модель навчання) та ін. Безперечно, такий ракурс вивчення професійного мовдення є важдивим для підготовки майбутніх педагогів, і в курсі української мови за професійним спрямуванням може бути реалізований під час розгляду теми «Переклад і редагування наукових текстів». У цьому контексті для формування професійного мовлення студентів вважаємо необхідним розкрити основні аспекти вживання прийменників у науковому та офіційно-діловому стилях. Як показує практика, складною для практичного засвоєння $є$ побудова конструкцій 3 прийменником по та помилкове його використання, пов'язане з упливом російської мови. Наприклад: завдання з української мови, з ініцзіативи учнів, проректор з наукової роботи, за наказом директора, працювати за сумісництвом, на запрошення, у службових

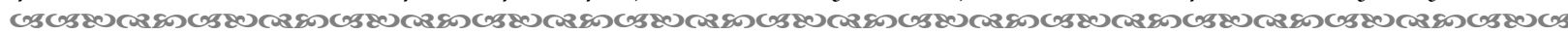


справах, щзоо справи, поштою, телефоном, щосереди. Значна частина помилок пов'язана з використання прийменника при в конструкціях, які в українській мові вживаються з іншими відповідниками, наприклад: за цзих умов, під час зустрічі, за життя педагога.

Предметом поодиноких наукових досліджень стали особливості вдосконалення орфоепічних, акцентуаційних та синтаксичних умінь студентів у процесі вивчення української мови за професійним спрямуванням. Зокрема, С. Харченко, аналізуючи ступінь висвітлення теоретико-практичних аспектів функціонування у фаховій мові синтаксичної норми, вказує на суперечливі твердження в посібнику «Ділове мовлення» О. Олійник, В. Шинкарука, Г. Гребницького [7] щодо використання пасивних і активних конструкцій. Крім того, у більшості посібників, за твердженням автора, синтаксичні теми відсутні взагалі. В окремих джерелах їх подання обмежуеться розкриттям зв' язку числівників з іменниками, вживанням безособових дієслівних форм у писемному й усному діловому мовленні та узгодженням власних назв з означуваним словом [12]. Водночас для вдосконалення синтаксичного ладу мовлення студентів важдиве значення має розгляд у теоретичному аспекті й практико орієнтована робота 3 таких питань: 1) прямий і непрямий порядок сдів, використання інверсії в офіційно-діловому стиді; 2) вживання вставних і вставлених конструкцій у текстах документів; 3) логікосемантичне завдання однорідних членів речення, типові порушення догічної однорідності та граматичного вираження; 4) складні випадки присудково-підметової координації у наукових та офіційно-ділових текстах; 5) скдадні випадки керування (напр., оволодіти українською мовою - опанувати украӥнську мову; властивий студентам характерний для студентів); 6) вживання розщеплених присудків у діловому мовленні; 7) помилки під час використання дієприслівникових зворотів. Мождивості для практичного вивчення наведених синтаксичних аспектів професійного мовлення створюються викладачем на кожному занятті: як аналіз студентського мовлення, доречний приклад, елемент створеної комунікативної ситуації. Теоретичний матеріал є елементом теми «Переклад і редагування наукових текстів» та дослідницьких проєктів у межах самостійної роботи студентів.

Від рівня засвоєння синтаксичних норм залежить пунктуаційна грамотність майбутніх фахівців. На жаль, питання пунктуаційних аспектів писемної професійної комунікації не знайшло належного висвітлення у науково-методичній літературі, як і дінгво-технологічні аспекти оформлення друкованого тексту.

Орфоепічна та акцентуаційна сторона фахового мовлення розкрита в праці 1. Прокопович, у якій акцентовано на вимові голосних і приголосних звуків, а також на випадках подвійного наголошування в українській мові [9]. Однак важкими для наукового опису, а відтак мадо представденими в інформаційному просторі залишаються питання інтонування наукового та ділового мовлення, годосової культури педагога.

Дінгвістичний підхід до навчання української мови за професійним спрямуванням реалізується і через аналіз типових мовних помилок студентів, що стало предметом дослідження науковців. Зокрема, О. Старова, Т. Панова до основних причин таких порушень відносять вплив територіальних діалектів і російської мови, недостатній рівень навчання української мови в 33СО, відсутність звички до читання, низьку мотивацію, показову свободу від обмежень [10, с. 131]. Дослідження усних і письмових текстів на наявність у них порушень норм української мови дозволяє об'єднати теорію і практику лінгвістичної підготовки, систематизувати отримані знання і перевести їх у комунікативну площину. Формуванню позитивної мотивації до такого виду роботи сприяють дослідницькі завдання не тільки стосовно студентського мовлення, але й мовлення викладачів, текстів оголошень, реклами, методичних матеріалів тощо.

Потенціал дінгвістичного підходу до навчання української мови за професійним спрямуванням не обмежується нормативним використанням одиниць усіх мовних рівнів. 32016 року спостерігається підвищення уваги науковців до реадізації

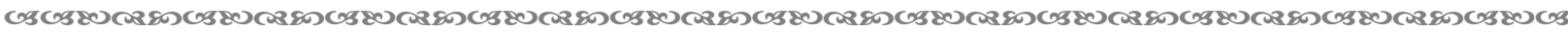
132 
прагмалінгвістичних категорій у змісті дисципліни [1;3]. Мова йде, зокрема, про мікропрагматичні одиниці професійного спілкування (добір лексичних і граматичних засобів, використання дейктичних маркерів), макропрагматичні (типи, форми, закони, стратегії і тактики комунікативної діяльності, врахування пресубпозиції, прагматика ввічливості) та мегапрагматичні елементи (специфіка побудови діалогу, врахування соціальної субординації, координація вербальної та невербальної поведінки, побудова текстів документного дискурсу) [3].

Як бачимо, сучасні дінгвістичні тенденції не оминають увагою потенціал використання екстралінгвістичних засобів у процесі комунікації. Водночас з моменту виникнення української мови за професійним спрямуванням як навчальної дисципліни опублікована незначна кількість досліджень специфіки їх використання у діловому мовленні [11;13], а методика навчання особливостям застосування позамовних засобів у професійному спілкуванні взагалі не була предметом вивчення. Хоча, на думку науковців, цей аспект комунікації має суттєвий вплив на ії перебіг і результативність, оскільки візуальне сприйняття дає мовцю до 65 \% необхідної інформації, в той час, як вербальне - до 35 \% [11, с. 58].

Висновки. Потенціал дінгвістичного та екстрадінгвістичного підходів до навчання української мови за професійним спрямуванням визначається необхідністю фахової підготовки майбутнього вчителя початкових класів, здатного забезпечити ефективність комунікативної взаємодії через правильне використання мовних і позамовних засобів спілкування. Мождивості досліджуваних підходів до навчання дисципліни охоплюють не тільки нормативне використання одиниць усіх мовних рівнів, але й реалізацію прагмалінгвістичних категорій та екстралінгвістичних аспектів у змісті курсу. Перспективи подальших наукових розвідок вбачаємо в грунтовному дослідженні функціонально-стилістичного підходу до формування професійно-мовленнєвої компетентності майбутніх фахівців початкової освіти.

\section{Список використаних джерел:}

1. Гамова Г.ІІ. Прагмалінгвістичні основи знань 3 ділової української мови в публічному управлінні. Розвиток професійних компетентностей державних службовиців: комунікативний аспект: матеріали щоріч. наук.-практ. конф. за міжнар. участю. Київ: НАДУ, 2016. С. 370-372.

2. Горох Г. В. Фразеологічні особливості ділового мовлення. Педагогічна освіта: теорія і практика. 2011. Вип. 8. С. 196-199.

3. Гуменюк I. М. Реалізація прагмалінгвістичних категорій у змісті мовно-професійної підготовки фахівців початкової школи. Гірська школа Українських Карпат. 2016. № 14. C. $170-173$.

4. Куньч 3. Вивчення особливостей вживання пасивних дієслівних конструкцій у курсі «Українська мова (за професійним спрямуванням)». Вісник Иьвівського університету. Серія філохогічна. 2010. Вип. 50. С. 239-245.

5. Пещенко Т. О. Вивчення норм лексичної сполучуваності у фаховій мові медика як засіб профілізації викладання ділової української мови. Сучасні підходи до викладання теоретичних i клінічних дисциилін у медичному вузі: матеріали конф. Полтава, 2005. С. 135-137.

6. Михайлюк В. О. Фразеологічні особливості ділового мовлення. Вересенъ. 1998. № 1-2. С. 91-94.

7. Олійник О. Б., Шинкарук В. Д., Гребницький Г. М. Ділове мовлення: навч. посібник. Київ: Кондор, 2009. 262 с.

8. Пасічна О.В. Удосконалення лексичних умінь і навичок студентів у процесі навчання української мови (за професійним спрямуванням). Педагогіка вищої та середньої школи. 2014. Вип. 40. С. 84-90.

9. Прокопович А. С. Формування орфоепічної та акцентуаційної компентності студентів ЗВО в процесі вивчення дисципліни «Українська мова за професійним спрямуванням». Науковий вісник Мукачівського державного університету. Серія «Педагогіка та психологія». 2019. Випуск 2 (10)/2. С. 42-45. 
10. Старова О. О., Панова Т. М. Типові мовні помилки й організація роботи з їх корекції під час викладання дисципліни «Українська мова (за професійним спрямуванням)». Викладання мов у вищих навчальних закладах освіти. 2015. Випуск 26. С. 127-134.

11. Харченко А. П. Особливості застосування невербальних засобів ділового спілкування. Соціальна педагогіка: теорія та практика. 2013. № 4. С. 58-65.

12. Харченко С. Питання синтаксичної норми на сторінках навчальних видань $з$ української фахової мови початку XXI ст. Гуманітарна освіта в технічних вищих навчальних закладах. Київ, 2012. C. $158-168$.

13. Якименко Н. Невербальні засоби ділового спілкування. Дивослово. 2003. № 5. С. 42-45.

\section{References:}

1. Hamova, H. I. (2016). Prahmalinhvistychni osnovy znan $z$ dilovoi ukrainskoi movy v publichnomu upravlinni [Pragmalinguistic bases of knowledge of Business Ukrainian language in Public Administration], Rozvytok profesiinykh kompetentnostei derzhavnykh sluzhbovtsiv: komunikatyvnyi aspekt, materialy shchorich. nauk.-prakt. konf. za mizhnar. uchastiu [Development of professional competencies of civil servants: communicative aspect, Proceedings of Annual Scientific and Practical Conference with international participation]. Kyiv [in Ukrainian].

2. Horokh, H. V. (2011). Frazeolohichni osoblyvosti dilovoho movlennia [Phraseological features of business speech]. Pedahohichna osvita: teoriia i praktyka, 8, 196-199 [in Ukrainian].

3. Humeniuk, I. M. (2016). Realizatsiia prahmalinhvistychnykh katehorii u zmisti movno-profesiinoi pidhotovky fakhivtsiv pochatkovoi shkoly [Implementation of pragmalinguistic categories in the content of language professional training of primary school teachers]. Hirska shkola Ukrainskykh Karpat, 14, 170-173 [in Ukrainian].

4. Kunch, Z. (2010). Vyvchennia osoblyvostei vzhyvannia pasyvnykh diieslivnykh konstruktsii u kursi «Ukrainska mova (za profesiinym spriamuvanniam)» [Teaching peculiarities of using passive verbal constructions in the course of "Ukrainian language for professional orientation"]. Visnyk Lvivskoho universytetu. Seriia filolohichna, 50, 239-245 [in Ukrainian].

5. Leshchenko, T. O. (2005). Vyvchennia norm leksychnoi spoluchuvanosti u fakhovii movi medyka yak zasib profilizatsii vykladannia dilovoi ukrainskoi movy [Study of norms of lexical compatibility in the professional language of a physician as a means of profiling the teaching of Business Ukrainian Language], Suchasni pidkhody do vykladannia teoretychnykh $i$ klinichnykh dystsyplin u medychnomu vuzi, materialy konf. [Modern approaches to teaching theoretical and clinical disciplines in medical higher educational institutions, Proceedings of Conference]. Poltava [in Ukrainian].

6. Mykhailiuk, V. O. (1998). Frazeolohichni osoblyvosti dilovoho movlennia [Phraseological features of business speech]. Veresen, 1-2, 91-94 [in Ukrainian].

7. Oliinyk, O. B., Shynkaruk, V. D., \& Hrebnytskyi, H. M. (2009). Dilove movlennia [Business speech]. Kyiv: Kondor [in Ukrainian].

8. Pasichna, O. V. (2014). Udoskonalennia leksychnykh umin i navychok studentiv u protsesi navchannia ukrainskoi movy (za profesiinym spriamuvanniam) [Improvement of the lexical skills of students in learning the Ukrainian language (for professional purposes)]. Pedahohika vyshchoi ta serednoi shkoly, 40, 84-90 [in Ukrainian].

9. Prokopovych, L. S. (2019). Formuvannia orfoepichnoi ta aktsentuatsiinoi kompentnosti studentiv ZVO v protsesi vyvchennia dystsypliny «Ukrainska mova za profesiinym spriamuvanniam» [Formation of orthoepic and accentuative competence of university students in the process of studying the discipline "Ukrainian language for professional purposes"]. Naukovyi visnyk Mukachivskoho derzhavnoho universytetu. Seriia «Pedahohika ta psykholohiia», 2(10)/2, 42-45 [in Ukrainian].

10. Starova, O. O., \& Panova, T. M. (2015). Typovi movni pomylky y orhanizatsiia roboty z yikh korektsii pid chas vykladannia dystsypliny «Ukrainska mova (za profesiinym spriamuvanniam)» [Typical language mistakes and the ways of organizing their correction in the course of teaching the Ukrainian language (for Specific Purposes)]. Vykladannia mov u vyshchykh navchalnykh zakladakh osvity, 26, 127-134 [in Ukrainian].

11. Kharchenko, L. P. (2013). Osoblyvosti zastosuvannia neverbalnykh zasobiv dilovoho spilkuvannia [Peculiarities of use of non-verbal means of business communication]. Sotsialna pedahohika: teoriia ta praktyka, 4, 58-65 [in Ukrainian]. 
12. Kharchenko, S. (2012). Pytannia syntaksychnoi normy na storinkakh navchalnykh vydan z ukrainskoi fakhovoi movy pochatku XXI stolittia [Syntactical norm issues on the pages of the Ukrainian professional language course books of the beginning of the XXI century]. Humanitarna osvita $v$ tekhnichnykh vyshchykh navchalnykh zakladakh, 158-168 [in Ukrainian].

13. Yakymenko, N. (2003). Neverbalni zasoby dilovoho spilkuvannia [Non-verbal means of business communication]. Dyvoslovo, 5, 42-45 [in Ukrainian].

Humeniuk I. M., orcid.org/0000-0002-0790-6732

\section{THE LINGUISTIC AND EXTRALINGUISTIC APPROACHES IN THE METHODOLOGY OF TEACHING UKRAINIAN LANGUAGE FOR PROFESSIONAL PURPOSES}

The article focuses on studying the potential of the linguistic and extralinguistic approaches to teaching the Ukrainian Language for Professional Purposes discipline at pedagogical institutions of higher education. The aim of the research is elucidation of the main ways of removal of the orthoepic, accentuating, lexical, syntactic and punctuational drawbacks of professional speech of future primary school teachers within the educational course. On the basis of analysis of the information space of the problem, it has been concluded that the prospects of using the linguistic approach in the context of Ukrainian Language for Professional Purposes are presented in an insignificant quantity of publications. The lexical aspect of professional speech is aimed at formation of the terminological competence of students and, partially, revealing of the methods of lexical combination in professional speech and removal of lexical mistakes. The relevance of the problems of excessive use of passive verb forms and incorrect formation of prepositional constructions in written business language is emphasized, as well as the opportunities for solving them within the course. The main aspects of improvement of the syntactic and punctuational arrangement of professional speech of students and unsolved issues in this context have been outlined.

The linguistic approach to teaching Ukrainian Language for Professional Purposes covers implementation of the pragmalinguistic categories in professional communication, particularly the micropragmatic (the speaker's level), macropragmatic (the recipient's level) and megapragmatic (the social level) units. The absence of research into the methodology of teaching the peculiarities of using extralinguistic means in professional communication is emphasized. The necessity of integrated application of the linguistic approach to teaching Ukrainian Language for Professional Purposes along with other conceptual approaches to language education has been confirmed.

Key words: professional speech, linguistic approach, extralinguistic approach, lexical norm, syntactic norm, pragmalinguistic categories, communication, linguistic competence.

Дата надходження статті: 22.04.2021 p. Рецеензент: доктор педагогічних наук, професор Білавич Г. В.

\section{ДОСЛІДЖЕННЯ ПРОФЕСІЙНО ВАЖАИВИХ ЯКОСТЕЙ МАЙБУТНЬОГО СУДНОВОДІЯ КРІЗЬ ПРИЗМУ АКМЕОЛОГІЧНОЇ КОМПЕТЕНЦІЇ}

У статті облрунтовано зміст поняття «професійна діяльність» щзоо професії судноводія, визначено ї̈ особливості та специфіку. Окреслено основні якості професійної діяльності судноводія та чинники, щео визначають ї спеццифіку. Акцентовано увагу

*C) Калашнік М. M.

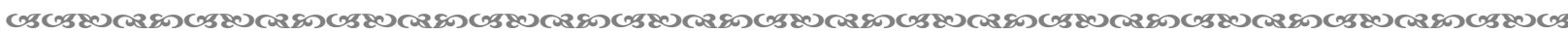

